\title{
ANALISIS HOMOGENITAS KEMAMPUAN BERPIKIR DAN PERILAKU SISWA (STUDI KASUS PADA PELAJARAN AGAMA ISLAM)
}

\section{THE HOMOGENEITY ANALYSIS COGNITIVE ABILITY AND STUDENT ATTITUDE (CASE STUDY ON THE ISLAMIC RELIGIOUS COURSE)}

\author{
Candra Wijaya \\ Universitas Islam Negeri Sumatera Utara, Indonesia \\ Email: candrawijaya@uinsu.ac.id
}

\section{Muhammad Syafi'i}

Sekolah Tinggi Agama Islam Al-Hikmah Medan, Indonesia Email: muhammadsyafii.shs@gmail.com

\section{Tongat}

Sekolah Tinggi Darul Arafah Medan, Indonesia

Email: tongat11@yahoo.com

\begin{abstract}
Abstrak
Kemampuan kognitif dan perilaku siswa pada mata pelajaran agama Islam masih rendah. Penelitian ini bertujuan untuk mengungkapkan kelayakan data yang diperoleh dari instrumen angket berdasarkan variabel kemampuan kognitif dan sikap. Pembuktian dilakukan dengan pendekatan kuantitatif dengan analisis homogenitas. Pemrosesan data dilakukan secara manual dengan persamaan matematika. Lokasi penelitian di SMA Swasta Imelda Medan. Populasi diperoleh dari seluruh kelas XI dengan jumlah sampel sebanyak 21 siswa. Waktu penelitian dilakukan mulai bulan Juli sampai september 2019. Skala likert dipilih sebagai instrumen angket dalam mengumpulkan data. Hasil penelitian menunjukkan bahwa semua atribut memiliki sebaran data yang homogen. Artinya adalah data yang diperoleh dari responden memiliki sebaran kesamaan ukuran sehingga layak untuk tahap analisis selanjutnya.
\end{abstract}

Kata Kunci: kemampuan kognitif, sikap, analisis homogenitas

\begin{abstract}
The cognitive ability and the student attitude on the Islamic religious course still low. This study aims to reveal a homogeneity analysis of cognitive abilities towards student attitudes that is the limited level. The proof was done with quantitative approach. The data processing was done manually with mathematical equations. The research location at Senior High School Imelda Medan. The total of 21 student was sampled drawn from the XI-Class. The activities were established from july to september 2019. The Likert scale has been suggested instruments to measure student cognitive ability toward influenced of the attituted. The results shows, all the attribute variables had a homogeneous. This means that the data obtained from respondents have a similarity in size distribution so it is feasible for the next stage of analysis.
\end{abstract}

Keywords: cognitive ability, attitude, homogeneity analysis 
Candra Wijaya, Muhammad Syafi'i, dan Tongat: Pengaruh Kemampuan Berpikir terhadap Perilaku Siswa (Studi Kasus pada Pelajaran Agama Islam)

\section{A. Pendahuluan}

Pendidikan merupakan faktor utama dalam pembentukkan pribadi manusia. Pendidikan sangat berperan dalam membentuk baik atau buruknya pribadi manusia menurut ukuran normatif. Menyadari akan hal tersebut, pemerintah sangat serius menangani bidang pendidikan, sebab dengan sistem pendidikan yang baik diharapkan muncul generasi penerus bangsa yang berkualitas dan mampu menyesuaikan diri untuk hidup bermasyarakat, berbangsa dan bernegara ${ }^{1}$. Reformasi pendidikan merupakan respon terhadap perkembangan tuntutan global sebagai suatu upaya untuk mengadaptasikan sistem pendidikan yang mampu mengembangkan sumber daya manusia untuk memenuhi tuntutan zaman yang sedang berkembang. ${ }^{2}$ Melalui reformasi pendidikan, pendidikan harus berwawasan masa depan yang memberikan jaminan bagi perwujudan hak-hak asasi manusia untuk mengembangkan seluruh potensi dan prestasinya secara optimal guna kesejahteraan hidup di masa depan.

Pendidikan adalah usaha sadar dan bertujuan untuk mengembangkan kualitas manusia. Sebagai kegiatan sadar akan tujuan, maka dalam pelaksanaannya berada dalam sebuah proses yang berkesinambungan dalam setiap jenis dan jenjang pendidikan yang integral. Pendidikan sebagai suatu sistem tersusun dan tidak dapat terpisahkan dari rangkaian unsur atau komponen yang berhubungan secara dinamis dalam suatu kesatuan. Pendidikan karakter yang melibatkan ketiga aspek itu merupakan pendidikan holistik yang akan bermanfaat untuk kemaslahatan manusia. ${ }^{3}$ Pembentukan karakter yang didambakan bukan hanya menjadikan orang tahu yang baik (kognitif atau pengetahuan), bukan pula hanya menjadikan orang yang dapat merasakan atau menilai yang baik (afektif atau perasaan), melainkan harus dapat menjadikan orang yang mau melakukan yang baik dan terbiasa melakukan kebajikan (psikomotorik atau aksi). Harus

\footnotetext{
${ }^{1}$ Setiawan, "Kajian Kurikulum Pendidikan Agama Islam dalam Tinjauan Historis, Sosiologi, Politis, Ekonomis dan Manajemen Negara," Darul Ulum: Jurnal Ilmiah Keagamaan, Pendidikan dan Kemasyarakatan, Vol. 9, No. 2 (2018): 253-275

${ }^{2}$ Wijaya, "Reformasi Pendidikan Islam," Prosiding Seminar Nasional, Vol. 105 (2016)).

${ }^{3}$ Ramdhani, "Lingkungan Pendidikan dalam Implementasi Pendidikan Karakter," Jurnal Pendidikan UNIGA, Vol. 8, No. 1 (2014): 28-37
} 
diciptakann metode pendidikan karakter yang dapat menjadikan orang sebagai pelakupelaku kebajikan. ${ }^{4}$

Peristiwa-peristiwa emosional yang terjadi silih berganti sejatinya turut memperkaya pengalaman hidup. Namun, harus mampu mengatasi semuanya. Bagi orang yang selalu mengedepankan cara pandang positif (positive thinking) akan berusaha memahami setiap peristiwa yang dialaminya dari sudut pandang positif. Sebaliknya, mereka yang mudah berpikir negatif (negative thingking) akan menilai sesuatu dengan kaca mata negatif. Lihat ilustrasi berikut ini: sebuah gelas bervolume $100 \mathrm{ml}$ diisi air sebanyak $50 \mathrm{ml}$. Jika kedua tipe manusia di atas diminta memberi komentar, maka yang berpikiran positif akan memandang bahwa gelas itu berisi separuh (ia lebih melihat isinya ketimbang kosongnya). Jika yang pertama menekankan pada "keberisiannya" (positif), maka yang berikutnya menekankan "kekosongan" (negatif).

Kognitif sangat mempengaruhi sikap dan perilaku. Uang dua puluh ribu rupiah mungkin teramat kecil manakala di bawa ke mal atau supermarket, tapi betapa besarnya jika dibawa ke kotak amal. Pertandingan sepak bola antar klub Eropa terasa cepat sekali waktu berlalu meski sudah dua kali empat puluh lima menit terpaku di atas kursi, tapi kadang-kadang betapa panasnya tempat duduk ketika kita membaca zikir atau ayat al-Qur'an yang mungkin hanya lima belas menit. Demikian kognitif dapat berperan meredakan emosi negatif, tergantung kita men-swich-nya ke arah yang tepat atau tidak. Penyusaian kognisi (cognitive adjustment) merupakan cara yang bisa dipakai untuk menilai sesuatu menurut paradigma subyek yang dapat disesuaikan dengan pemahaman yang dikehendaki, antara lain dalam bentuk atribusi positif (peta mental) dicoba untuk dicocokkan dengan berbagai hal yang paling mungkin dan pas untuk diyakini. Kemampuan kognitif menggambarkan penguasaan ilmu pengetahuan dan teknologi tiap-tiap orang. Pada dasarnya kemampuan kognitif merupakan hasil belajar. Tanpa ranah kognitif, sulit dibayangkan seorang siswa dapat berfikir. Selanjutnya, tanpa kemampuan berfikir mustahil siswa tersebut dapat memahami dan meyakini faedah.

Penghayatan para remaja terhadap ajaran agama dan tindak keagamaan yang tampak pada para remaja banyak berkaitan dengan perkembangan sikap yang dimiliki. ${ }^{5}$

${ }^{4}$ A. R. Amalia, M. Bakri, dan M. Sulistiono, "Sistem Pembelajaran Pendidikan Agama Islam (Analisis Kritis Teori Konvergensi di SMA Islam Almaarif Singosari)," Vicratina: Jurnal Pendidikan Islam, Vol. 4, No. 3 (2019): 111

${ }^{5}$ Wati, "Memahami Perkembangan Jiwa Keagamaan pada Anak dan Remaja," FOKUS Jurnal Kajian Keislaman dan Kemasyarakatan, Vol. 1, No. 1 (2016): 21 
Candra Wijaya, Muhammad Syafi'i, dan Tongat: Pengaruh Kemampuan Berpikir terhadap Perilaku Siswa (Studi Kasus pada Pelajaran Agama Islam)

Penelitian yang terkait dengan kemampuan berpikir dalam penghayatan keagamaan di kalangan remaja telah banyak dilakukan, beberapa contohnya adalah yang dilakukan oleh Yahya dan Nasrun ${ }^{6}$ yang menyatakan bahwa para remaja di Malaysia cenderung lebih mengutamakan tindakan ataupun perbuatan dari pada nilai-nilai keagamaan yang telah diperolehnya dilingkungan rumah dan juga di sekolah. Penelitian yang telah dikerjakan oleh Roszi $^{7}$ menggambarkan hubungan antara kemampuan berpikir dan perilaku akhlakul karimah yang terbentuk oleh ilmu, lingkungan yang baik dan kemampuan yang tidak mendukung. Elihami dan Syahid ${ }^{8}$ melakukan pendekatan interdisipliner kemampuan kognitif dan sikap melalui manajemen, pedagogis, sosiologi, dan psikologis.

Berdasarkan hal yang telah dikemukakan tersebut dan banyak penelitian yang telah dilakukan terhadap kemampuan kognitif dan sikap keagamaan pada mata pelajaran agama Islam belum ada yang mengungkapkan secara baik terhadap analisis data secara homogen pada asumsi bahwa siswa yang memiliki kemampuan kognitif baik maka keyakinan dan penghayatan siswa menjadi kuat jika dilandasi oleh pengetahuan dan pemahamannya terhadap ajaran dan nilai agama Islam, sehingga siswa dapat merealisasikan dalam bentuk sikap keagamaan yang baik pada kehidupan sehari-hari. Sedangkan siswa yang memiliki kemampuan kognitif kurang baik maka keyakinan dan penghayatan siswa menjadi lemah yang pemahamannya tidak dilandasi oleh pengetahuan dan perilaku yang cukup terhadap ajaran dan nilai agama Islam.

Begitu pentingnya peranan mata pelajaran agama Islam seperti yang diuraikan di atas, seharusnya membuat pelajaran agama Islam menjadi salah satu mata pelajaran yang menyenagkan dan digemari oleh siswa. Namun demikian, tidak dapat dipungkiri lagi bahwa mata pelajaran agama Islam merupakan pelajaran yang dianggap membosankan dan sering menimbulkan kurang minatnya dalam belajar dan mengalami penurunan dalam hasil belajar. Kondisi ini mengakibatkan mata pelajaran agama Islam tidak disenangi, tidak diperdulikan dan bahkan diabaikan. Hal ini tentunya menimbulkan kesenjangan yang cukup besar antara apa yang diharapkan dari pelajaran

\footnotetext{
${ }^{6}$ S.A. Yahya, and S. Nasrun, "Tahap Penghayatan Agama Dalam Kalangan Remaja Hamil Tanpa Nikah,” Jurnal Sains Sosial@ Malaysian Journal of Social Sciences, Vol. 1, No. 1 (2016): 19

${ }^{7}$ Roszi, "Tipologi Perilaku Keagamaan Siswa dan Kemampuan Kognitif pada Pembelajaran Pendidikan Agama Islam di MTs. Batang Kabung Kota Padang," Jurnal El-Rusyd, Vol. 1, No. 1 (2017): 83

${ }^{8}$ Elihami dan Syahid, "Penerapan Pembelajaran Pendidikan Agama Islam dalam Membentuk Karakter Pribadi yang Islami," Edumaspul: Jurnal Pendidikan, Vol. 2, No. 1 (2018): 80
} 
agama Islam dengan kenyataan yang terjadi di lapangan dan tentunya kehidupan seharihari bahkan diri sendiri. Di satu sisi mata pelajaran agama Islam mempunyai peranan penting dalam kehidupan sehari-hari, yaitu meningkatkan keimanan, akhlak, berpikir logis, sistematis dan ketakwaan terhadap Allah SWT.

\section{B. Kajian Teoretis}

\section{Kemampuan Kognitif}

Teori-teori kognitif didasarkan pada asumsi bahwa kemampuan kognitif merupakan sesuatu yang fundamental dan yang membimbing tingkah laku anak. Dengan kemampuan kognitif ini maka anak dipandang sebagai individu yang secara aktif membangun sendiri pengetahuan mereka tentang dunia. Perkembangan kognitif merupakan salah satu perkembangan manusia yang berkaitan dengan pengetahuan, yakni semua proses psikologis yang berkaitan dengan bagaimana individu mempelajari dan memikirkan lingkungannya. ${ }^{9}$.

Dalam kamus psikologi pembelajaran, kemampuan adalah "kesanggupan; kecakapan; kekuatan." "Sedangkan Mardianto mendefinisikan "kemampuan sebagai karakteristik yang menonjol dari seorang individu yang berhubungan dengan kinerja afektif dan superior dalam suatu pekerjaan atau situasi."11 Dalam sekian banyak kajian tentang proses berpikir pada anak-anak dalam usia yang berberda-beda. Tahap sensorimotorik seperti layaknya pemikiran bayi termasuk ke dalam pemikiran sensorismotorik, tahap sensorismotorik berlangsung dari kelahiran bayi hingga kira-kira usia 2 tahun. Selama tahap ini perkembangan mental ditandai dengan perkembangan pesat dengan kemampuan bayi untuk mengorganisasikan dan mengkoordinasikan sensasi melalui gerakan-gerakan dan tindakan fisik. ${ }^{12}$

Tahap praoperasional yang merupakan konsep-konsep yang stabil dibentuk, penalaran mental muncul, egosentrisme mulai kuat dan kemudian melemah, serta terbentuknya keyakinan terhadap hal yang magis. Pemikiran praoperasional merupakan tahap awal dari pemikiran operasional. Menurut Piaget operasi adalah hubungan logis

\footnotetext{
${ }^{9}$ Syah, Psikologi Belajar (Jakarta: Raja Grafindo Persada. 2009), 97.

${ }^{10}$ Poerwadarminta, Kamus Baru Dalam Psikologi Pembelajaran (Jakarta: Bumi Aksara. 2008), 176

${ }^{11}$ Mardianto, Psikologi Pendidikan (Medan: Cita Pustaka. 2009), 89.

${ }^{12}$ Saripudin, "Analisis Tumbuh Kembang Anak Ditinjau dari Aspek Perkembangan Motorik Kasar Anak Usia Dini,” Equalita: Jurnal Pusat Studi Gender dan Anak, Vol. 1, No. 1 (2019): 116
} 
Candra Wijaya, Muhammad Syafi'i, dan Tongat: Pengaruh Kemampuan Berpikir terhadap Perilaku Siswa (Studi Kasus pada Pelajaran Agama Islam)

diantara konsep-konsep atau skema-skema. ${ }^{13}$ Sedangkan operasi konkret adalah aktifitas mental yang difokuskan pada objek-objek atau pristiwa-pristiwa nyata atau konkret dapat diukur. Anak-anak pada tahap operasional konkret sudah mengembangkan pikiran logis dan mulai mampu memahami operasi sejumlah konsep.

Tahap operasional formal dimana, anak sudah mulai berpikir abstrak dan hipotesis. Pada masa ini anak sudah mampu memikirkan sesuatu yang akan atau mungkin terjadi, sesuatu yang abstrak. ${ }^{14}$ Di samping itu, pada tahap ini remaja juga sudah mampu berpikir secara sistematik. Remaja telah mampu memikirkan semua kemungkinan secara sistematik untuk memecahkan masalah. Mereka juga memiliki kemampuan berpikir alternatif, sehingga memungkinkan menyelesaikan masalah yang mereka hadapi lebih beragam. Aspek kognitif yang menonjol di dalam kehidupan manusia ialah kecerdasan. Kecerdasan manusia terdiri dari beberapa aspek yang salah satunya ialah kemampuan bahasa. Perkembangan kognitif anak dipengaruhi beberapa hal, seperti perawatan kesehatan, keadaan gizi, dan stimulasi mental yang diberikan oleh lingkungan sangat besar pengaruhnya bagi pertumbuhan kecerdasan. ${ }^{15}$

Dalam klasifikasi taksonominya, Bloom mengemukakan enam tingkatan kognitif meliputi kemampuan untuk mengenal atau mengingat kembali tentang sesuatu. Misalnya hafalan tentang hal-hal khusus, pengetahuan tentang cara dan sarana tentang hal-hal khusus, pengetahuan universal dan abstraksi. Kemampuan untuk memahami sesuatu yang berarti mengetahui terlebih dahulu tentang sesuatu hal serta melihatnya dari berbagai segi, apakah dengan menguaraikann, menerangkan, atau memperluas arti suatu istilah. Proses berpikir yang setingkat lebih tinggi dari pemahaman. Dalam aplikasi, siswa diharapkan mampu memilih, menggunakan, dan menerapkan dengan tepat suatu teori, hukum, atau metode pada situasi baru atau situasi lain ${ }^{16}$.

Kemampuan untuk merinci atau menguraikan suatu bahan atau keadaan menurut bagian-bagian yang lebih kecil (komponen) atau faktor-faktor penyebabnya dan mampu memahami hubungan di antara bagian/faktor yang satu dengan lainnya. Kemampuan berpikir yang merupakan kebalikan dari dari proses analisis, suatu proses yang

\footnotetext{
${ }^{13}$ Hijriati, "Tahapan Perkembangan Kognitif pada Masa Early Childhood," Bunayya: Jurnal Pendidikan Anak, Vol. 1, No. 2 (2017): 35

${ }^{14}$ Sitorus, Perkembangan Peserta Didik (Depok: Kencana, 2017), 68.

${ }^{15}$ Goleman, Kecerdasan Emosional (Jakarta: Gramedia Pustaka Utama, 2000), 212

${ }^{16}$ Masrom, et.al., Kedudukan Taksonomi Bloom Menurut Perspektif Islam," Journal of Quran Sunnah Education \& Special Needs, Vol. 2, No. 1 (2018): 20
} 
memadukan bagian-bagian, atau unsur secara logis sehingga menjadi suatu pola struktur atau bentuk yang baru. Merupakan jenjang tertinggi dalam kognitif, yang merupakan kemampuan untuk dapat memberikan pertimbangan terhadap suatu situasi, nilai-nilai, ide-ide berdasarkan patokan atau kriteria tertentu. Misalnya, jika seseorang dihadapkan pada beberapa pilihan yang terbaik sesuai dengan kriteria tertentu. Kriteria ini dilihat dari berbagai segi seperti ketepatgunaan, ketapatan waktu, dampak atau efek samping, keuntungan dan kerugiannya, dan sebagainya.

\section{Sikap Remaja Terhadap Agama}

Sikap dapat didefinisikan sebagai berikut: "kesiapan pada seseorang untuk bertindak secara tertentu terhadap hal-hal tertentu." ${ }^{\prime 7}$ Pendapat lain mengatakan bahwa "sikap merupakan predisposisi untuk bertindak senang atau tidak senang terhadap objek tertentu yang mencakup komponen kognisi, afksi, dan konasi." Sikap adalah kecenderungan untuk bertindak berkenaan dengan objek tertentu. Dalam istilah kecenderungan (predisposition) terkandung pengertian arah tindakan yang akan dilakukan seseorang berkenaan dengan suatu objek. Arah tersebut dapat bersifat mendekati atau menjauhi. Tindakan mendekati atau menjauhi suatu objek (orang, benda, ide, lingkungan dan lain-lain) dilandasi oleh perasaan penilaian individu yang bersangkutan terhadap objek tersebut. ${ }^{18}$

Walaupun sikap terbentuk karena pengaruh lingkungan namun faktor individu itu sendiri ikut pula menentukan. Dengan demikian, walaupun sikap keagamaan bukan merupakan bawaan akan tetapi dalam pembentukan dan perubahannya ditentukan oleh faktor internal dan faktor eksternal individu. Adapun faktor-faktor yang mempengaruhi sikap keagamaan yaitu faktor internal bahwa manusia sudah memiliki potensi untuk beragama. Faktor eksternal yakni pembawaan atau fitrah beragama merupakan potensi yang mempunyai kecenderungan untuk berkembang memberikan rangsangan atau stimulus yang memungkinkan fitrah itu berkembang dengan sebaik-baiknya. Faktor eksternal itu tiada lain adalah lingkungan di mana individu itu hidup.

Keagamaan berasal dari kata agama, agama menyangkut kehidupan batin manusia. Menurut Nasution, agama mengandung arti ikatan yang harus dipegang dan

\footnotetext{
${ }^{17}$ Amir, Merancang Kuesioner: Konsep dan Panduan untuk Penelitian Sikap, Kepribadian, dan Perilaku (Jakarta: Prenada Media, 2017), 78

${ }^{18}$ Jayanti dan Silaen, "Hubungan antara Keharmonisan Keluarga dan Kecerdasan Emosi dengan Kecenderungan Perilaku Delinkuen pada Siswa SMK Adi Luhur 2 Jakarta Timur." IKRA-ITH HUMANIORA: Jurnal Sosial dan Humaniora, Vol. 3, No. 2 (2019): 47
} 
Candra Wijaya, Muhammad Syafi'i, dan Tongat: Pengaruh Kemampuan Berpikir terhadap Perilaku Siswa (Studi Kasus pada Pelajaran Agama Islam)

dipatuhi manusia. Ikatan dimaksud berasal dari suatu kekuatan yang lebih tinggi dari manusia sebagai kekuatan gaib yang tak dapat ditangkap dengan panca indera, namun mempunyai pengaruh yang besar sekali terhadap kehidupan manusia sehari-hari. Agama adalah risalah yang disampaikan Tuhan kepada Nabi sebagai petunjuk bagi manusia dan hukum-hukum sempurna untuk dipergunakan manusia dalam menyelenggarakan tata cara hidup yang nyata serta mengatur hubungan dengan dan tanggungjawab kepada Allah SWT, kepada masyarakat serta alam sekitarnya. ${ }^{19}$ Agama adalah risalah yang disampaikan Tuhan kepada Nabi sebagai petunjuk bagi manusia dan hukum-hukum sempurna untuk dipergunakan manusia dalam menyelenggarakan tata cara hidup yang nyata serta mengatur hubungan dengan dan tanggungjawab kepada Allah SWT, kepada masyarakat serta alam sekitarnya. ${ }^{20}$

Jadi sikap keagamaan merupakan integrasi secara kompleks antara pengetahuan agama, perasaan agama serta tindak keagamaan dalam diri seseorang. Untuk menanamkan sikap terhadap nilai-nilai atau norma-norma agama maupun norma-norma sosial, anak harus diberikan pengertian yang cukup jelas mengenai manfaat dan keburukan bila melanggar norma-norma tersebut dengan penjelasan yang bisa diterima, artinya sesuai dengan tingkat perkembangan mereka. Orang dewasa sebaiknya tidak hanya sekedar memberi contoh, tetapi harus menjadi contoh dalam kehidupan seharihari. Dengan kalimat yang lebih menunjuk ialah lingkungan harus turut mendukung nilai-nilai pendidik. Keramahan tidak dapat diperoleh dari seorang pemarah, rendah diri tak dapat ditimba dari orang yang sombong dan seterusnya. Kecuali penanam pengertian dan contoh nyata juga masih perlu penghargaan. Anak merasa mantap bahwa sesuatu hal itu baik atau buruk sangat tergantung dari pengalaman yang mereka lalui, bila sesuatu dihargai oleh lingkungannya, mereka selanjutnya berusaha untuk tetap melakukannya dan sebaliknya.

\section{Mata Pelajaran Pendidikan Agama Islam}

Pengertian pendidikan agama Islam, dapat ditinjau dari secara sempit dan luas. Pengertian secara sempit adalah usaha yang dilakukan untuk pentransferan ilmu (knowledge), nilai (value) dan keterampilan (skill) berdasarkan agama Islam dari si

\footnotetext{
${ }^{19}$ Nasution, Filsafat Islam (Jakarta: Gaya Media Pratama, 1999), 65

${ }^{20}$ Ahmadi dan Salimi, Dasar-dasar Pendidikan Agama Islam (Jakarta: Bumi Aksara, 1991), 114
} 
pendidik kepada si terdidik guna terbentuk pribadi muslim seutuhnya, ${ }^{21}$ seperti firman Allah SWT dalam surah al-Baqarah ayat 75 yang berbunyi:

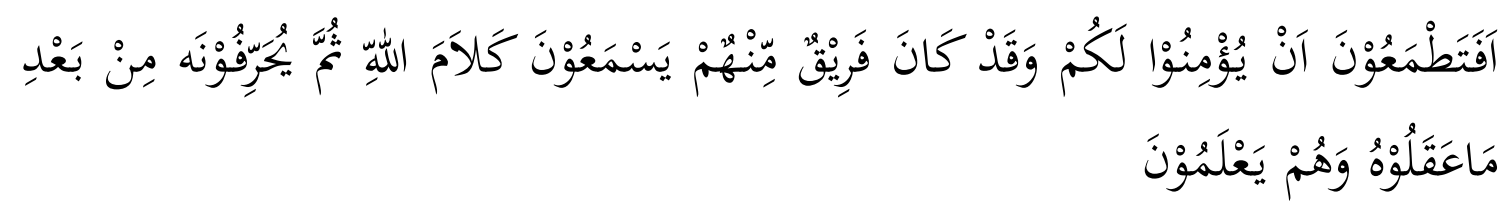

“Apakah kamu masih mengharapkan mereka akan percaya kepadamu, padahal segolongan dari mereka mendengar firman Allah, lalu mereka mengubahnya setelah mereka memahaminya, sedang mereka mengetahui."

Menurut Said, pendidikan agama Islam adalah keseluruhan daya budaya yang mempengaruhi kehidupan perorangan maupun kelompok dalam dalam masyarakat yang berdasarkan norma-norma agama Islam menuju terwujudnya kepribadian yang utama menurut kriteria Islam. ${ }^{22}$ Menurut Basri, pendidikan agama Islam adalah usaha yang dilakukan untuk penstransferan ilmu yang bermanfaat bagi kehidupan manusia, baik terhadap aktivitas jasmaninya, pikiran-pikirannya maupun ketajaman dan kelembutan hati nuraninya yang berbasis kepada al-Qur'an dan al-Sunnah. ${ }^{23}$ Maka dari uraian di atas dapat disimpulkan bahwa pendidikan agama Islam adalah usaha yang dilakukan untuk pentransferan ilmu, nilai dan keterampilan serta segala aspek yang berkenaan dengan pendidikan Islam dari pendidik kepada peserta didik guna terbentuk pribadi muslim seutuhnya.

Mata pelajaran agama Islam sendiri merupakan salah satu mata pelajaran wajib ada dan diajarkan pada suatu jenjang pendidikan, baik sekolah dasar, sekolah menengah, sekolah menengah atas, maupun perguruan tinggi. Ahmadi menyatakan bahwa ada banyak alasan tentang perlunya siswa belajar agama Islam, yaitu:
a. Merupakan sarana memperbaiki akhlak
b. Sarana memecahkan masalah kehidupan sehari-hari
c. Sarana mengenal pola-pola hubungan dan generalisasi pengalaman.
d. Sarana mengembangkan keimanan.
e. Saranan untuk meningkatkan kesadaran terhadap perkembangan budaya. ${ }^{24}$

\footnotetext{
${ }^{21}$ Putra, Konsep Pendidikan Agama Islam Perspektif Imam Al-Ghazali. Jurnal Pendidikan Agama Islam Al-Thariqah, Vol. 1, No. 1 (2017): 42

${ }^{22}$ Said, Filsafat Pendidikan Islam (Yogyakarta: Mitra Usaha, 2011), 86

${ }^{23}$ Basri, Filsafat Pendidikan Islam (Bandung, Pustaka Setia, 2009), 124

${ }^{24}$ Ahmadi, Ilmu Pendidikan (Jakarta: Rineka Cipta, 2003), 113
} 
Candra Wijaya, Muhammad Syafi'i, dan Tongat: Pengaruh Kemampuan Berpikir terhadap Perilaku Siswa (Studi Kasus pada Pelajaran Agama Islam)

Strategisnya peranan mata pelajaran pendidikan agama Islam menjadi salah satu mata pelajaran yang diupayakan agar menjadi sejalan antara kemampuan kognitif dan sikap serasi dan selaras yang dikuasai oleh peserta didik. Upaya tenaga pendidik untuk membiasakan hal tersebut, namun demikian, tidak dapat dipungkiri lagi bahwa mata pelajaran agama Islam merupakan pelajaran yang dianggap membosankan dan sering menimbulkan kurang minatnya dalam belajar dan mengalami penurunan dalam hasil belajar oleh karena strategi, metode dan teknik pembelajaran yang cenderung monoton. Kondisi ini menjadi suatu keharusan untuk berubah pembelajaran lebih bermakna dan menjadi pembelajaran sepanjang hayat. Untuk itu tidak pernah bosan dan jemu para pendidik pada mata pelajaran agama Islam agar siswa tetap mengimplementasikannya pada kehidupan sehari-hari.

\section{Metode Penelitian}

Metode penelitian yang digunakan adalah jenis penelitian dengan pendekatan kuantitatif, sehingga alat untuk pengumpulan data (instrumen) yang sesuai dan juga diperlukan berupa lembar angket (kuesioner). Waktu penelitian dimulai dari bulan Juli sampai September 2019 yang berlokasi di Sekolah Menengah Atas Swasta Imelda Medan, Sumatera Utara. Populasi yang ada adalah seluruh siswa kelas XI sebanyak 1 lokal yang berjumlah 21 orang siswa. Menurut Yusuf, apabila populasi sangat kecil yakni kurang dari 31 responden maka seluruh populasi dapat dijadikan sampel. ${ }^{25}$ Uji homogenitas dilakukan dengan menggunakan rumus sederhana $\mathrm{F}=$ varian terbesar/ varian terkecil. ${ }^{26}$ Rumus untuk menentukan degree of freedom adalah $\mathrm{df}(\mathrm{n} 1)=\mathrm{k}-1 \mathrm{dan}$ df $(\mathrm{n} 2)=\mathrm{n}-\mathrm{k}$, dengan asumsi bahwa jika hasil $\mathrm{F}$ hitung yang diperoleh lebih kecil dari $\mathrm{F}$ tabel dengan taraf nyata sebesar 0,05 maka data bersifat homogen, namun jika sebaliknya maka data tidak homogen. ${ }^{27}$ Untuk mengetahui apakah data telah homogen dilakukan secara manual tanpa bantuan perangkat lunak (soft ware).

\footnotetext{
${ }^{25}$ Yusuf, Metode Penelitian Kuantitatif, Kualitatif dan Penelitian Gabungan (Jakarta: Kencana Prenadamedia Group. 2014), 87

${ }^{26}$ Dudek, "Homogenity Analysis of Copper Abundance in CU-AG Lubin Deposit using Statistical Procedures," International Multidisciplinary Scientific GeoConference: SGEM, Vol. 19, No. 1.1 (2019): 260

${ }^{27}$ Lillo Flores dan Romo, "Homogeneity Test for Functional Data," Journal of Applied Statistics, Vol. 45, No. 5 (2018): 870; Michailidis dan de Leeuw, "Multilevel Homogeneity Analysis with Differential Weighting," Computational Statistics \& Data Analysis, Vol. 32, No. 3-4 (2000): 422; Tenenhaus dan Young, "An Analysis and Synthesis of Multiple Correspondence Analysis, Optimal Scaling, Dual Scaling, Homogeneity Analysis and Other Methods for Quantifying Categorical Multivariate Data," Psychometrika, Vol. 50, No. 1 (1985: 100; Gabriel, "A Procedure for Testing the Homogeneity of All Sets of Means in Analysis of Variance," Biometrics, Vol. 20, No. 3 (1964): 470
} 
Kemudian untuk tata cara pemberian skor yaitu menggunakan skala Likert. Alternatif jawaban setiap pertanyaan dalam kuisionerini ada 5 macam, yaitu Sangat Sering (SS), Sering (S), Kadang-kadang (KK), Jarang (J), dan Tidak Pernah (TP). Untuk setiap pertanyaan (item) positif dalam kuisioner diberi bobot $S S=5, S=4, K K=3$, $\mathrm{J}=2, \mathrm{TP}=1$ sedangkan untuk pertanyaan (item) negatif sebaliknya, yaitu dengan bobot masing-masing 1, 2, 3, 4, dan 5. Adapun kisi-kisi instrumen yang digunakan untuk mengumpulkan data kemampuan kognitif seperti tabel berikut:

Tabel 1. Indikator Kemampuan Kognitif

\begin{tabular}{clcl}
\hline No & \multicolumn{1}{c}{ Indikator } & Jumlah & \multicolumn{1}{c}{ Nomor Butir Item } \\
\hline 1 & Pengetahuan/hapalan/ingatan & 5 & $1,2,3,4,5$ \\
2 & Pemahaman (comprehension) & 5 & $6,7,8,9,10$ \\
3 & Analisis (analysis) & 5 & $11,12,13,14,15$ \\
4 & Penilaian (evaluasi) & 5 & $16,17,18,19,20$ \\
\hline
\end{tabular}

Adapun kisi-kisi instrumen yang digunakan untuk mengumpulkan data dari variabel kemampuan sikap adalah:

Tabel 2. Indikator Kemampuan Sikap

\begin{tabular}{clcl} 
No. & \multicolumn{1}{c}{ Indikator } & Jumlah & \multicolumn{1}{c}{ Nomor Butir Item } \\
\hline 1 & Afektif siswa & 5 & $1,2,3,4,5$ \\
2 & Kepatuhan terahadap Tugas & 5 & $6,7,8,9,10$ \\
3 & Minat dalam belajar & 5 & $11,12,13,14,15$ \\
4 & Kedisiplinan dalam belajar & 5 & $16,17,18,19,20$ \\
\hline
\end{tabular}

\section{Hasil Penelitian dan Pembahasan}

Untuk mengetahui pengaruh kemampuan kognitif diatas, setelah dilakukan penjumlahan skor angket penelitian maka diperoleh totalitas skor angket variabel pengaruh kognitif. Hasil pengumpulan angket yang dilakukan terhadap 21 responden yaitu pengaruh kognitif siswa diketahui bahwa skor tertinggi adalah 88 dan skor terendah adalah 61. Selanjutnya perolehan dari keseluruhan total skor angket variabel pengaruh kognitif siswa dikemukakan sebagai berikut:

a. Range $(\mathrm{R})=$ Data Tertinggi - Data Terendah

$$
\begin{aligned}
& =88-61 \\
& =27
\end{aligned}
$$


Candra Wijaya, Muhammad Syafi'i, dan Tongat: Pengaruh Kemampuan Berpikir terhadap Perilaku Siswa (Studi Kasus pada Pelajaran Agama Islam)

b. Banyaknya Kelas $=1+(3,3) \log n$

$$
\begin{aligned}
& =1+(3,3) \log 21 \\
& =5,36(\text { digenapkan jadi } 5)
\end{aligned}
$$

c. Panjang Kelas $25 / 5=5$

Berikut merupakan tabel hasil perhitungan secara manual terhadap distribusi kemampuan kognitif yang diperoleh.

\begin{tabular}{|c|c|c|c|c|c|c|}
\hline No & Interval Kelas & $\mathrm{f}_{\mathrm{i}}$ & $\mathrm{X}_{\mathrm{i}}$ & $x i^{2}$ & fi xi & $f i x i^{2}$ \\
\hline 1 & $61-65$ & 1 & 63 & 3969 & 63 & 3969 \\
\hline 2 & $66-70$ & 2 & 68 & 4624 & 136 & 9248 \\
\hline 3 & $71-75$ & 2 & 73 & 5329 & 146 & 10658 \\
\hline 4 & $76-80$ & 7 & 78 & 6084 & 546 & 42588 \\
\hline 5 & $81-85$ & 8 & 83 & 6889 & 664 & 55112 \\
\hline 6 & $86-90$ & 1 & 88 & 7744 & 88 & 7744 \\
\hline & Jumlah & 21 & 453 & 34639 & 1643 & 129229 \\
\hline
\end{tabular}

Tabel 3. Distribusi Kemampuan Kognitif

Selanjutnya secara keseluruhan perolehan data tersebut yang juga sekaligus untuk mengetahui mean, varians, dan simpangan baku dapat dilihat dan dicermati melalui rumus matematika berikut:

a. Perhitungan Mean $x=\frac{\sum \mathrm{fi} \mathrm{xi}}{\mathrm{fi}}$ $=\frac{1603}{21}$ $=76,3$

b. MenentukanVarians $S^{2}=\frac{n \sum f i x i-\sum(f i x i)^{2}}{N(n-1)}$

$=\frac{21(129229)-2699449}{21(20)}$

$=\frac{2713809-2699449}{420}$

$=\frac{14360}{420}$

$=34,2$ 
c. Menentukan Simpangan Baku

Dari hasil varians di atas maka dapat dicari harga simpangan baku (S), di mana harga simpangan baku adalah akar varians yaitu $\sqrt{34,2}=5,85$. Dengan demikian, maka simpangan bakunya adalah 5,85.

Untuk mengetahui sikap, maka pengambilan data dari nilai formatif siswa. Hasil pengumpulan nilai formatif yang dilakukan terhadap 21 siswa/responden yaitu sikap keagamaan siswa diketahui bahwa hasil skor tertinggi adalah 91 dan skor terendah adalah 66. Selanjutnya perolehan dari keseluruhan total skor sikap sebagai berikut:

a. Range $(\mathrm{R})=$ Data Tertinggi - Data Terendah

$$
\begin{aligned}
& =91-66 \\
& =25
\end{aligned}
$$

b. Banyaknya Kelas $=1+(3,3) \log n$

$$
\begin{aligned}
& =1+(3,3) \log 21 \\
& =5,36(\text { digenapkan jadi } 5)
\end{aligned}
$$

c. Panjang Kelas $=25 / 5=5$

\begin{tabular}{|c|c|c|c|c|c|c|}
\hline No & Interval Kelas & $\mathrm{Fi}$ & $\mathrm{Yi}$ & $y i^{2}$ & fi yi & fi $\mathrm{yi}^{2}$ \\
\hline 1 & $66-70$ & 6 & 68 & 4624 & 408 & 27744 \\
\hline 2 & $71-75$ & 3 & 73 & 5329 & 219 & 15987 \\
\hline 3 & $76-80$ & 5 & 78 & 6084 & 390 & 30420 \\
\hline 4 & $81-85$ & 6 & 83 & 6889 & 498 & 41334 \\
\hline \multirow[t]{2}{*}{5} & $86-91$ & 1 & 88 & 7744 & 88 & 7744 \\
\hline & Jumlah & 21 & 107 & 30670 & 1603 & 123229 \\
\hline
\end{tabular}

Berikut merupakan tabel hasil perhitungan secara manual terhadap distribusi kemampuan sikap yang diperoleh.

Tabel 4. Distribusi Kemampuan Sikap

Selanjutnya secara keseluruhan perolehan data kemampuan sikap tersebut yang juga sekaligus untuk mengetahui mean, varians, dan simpangan baku dapat dilihat dan dicermati melalui rumus matematika berikut:

a. Perhitungan Mean $x=\frac{\sum \text { fi yi }}{\text { yi }}$

$=\frac{1603}{21}$

$=76,3$ 
Candra Wijaya, Muhammad Syafi'i, dan Tongat: Pengaruh Kemampuan Berpikir terhadap Perilaku Siswa (Studi Kasus pada Pelajaran Agama Islam)

b. Menentukan Varians $S^{2}=\frac{n \sum \text { fi yi- }-\sum(f i ~ y i)}{2}$

$=\frac{21(123229)-(1603)^{2}}{21(20)}$

$=43,3$

c. Menentukan Simpangan Baku

Dari hasil varians di atas maka dapat dicari harga simpangan baku (S), di mana harga simpangan baku adalah akar varians yaitu $\sqrt{ } 43,3=6,58$. Dengan demikian, maka simpangan bakunya adalah 6,58 .

d. Uji Homogenitas

Pengujian homogenitas menggunakan rumus $\mathrm{F}=\frac{\text { varian terbesar }}{\text { varian terkecil }}$ dengan ketentuan df $(\mathrm{n} 1)=\mathrm{k}-1$ yakni $2-1=1$ dan df $(\mathrm{n} 2)=\mathrm{n}-\mathrm{k}$ yakni $21-2=19$. Sesuai perhitungan terdahulu diketahui bahwa varian data kemampuan kognitif sebesar 34,2 dan kemampuan sikap sebesar 43,3. Dengan demikian harga $F$ hitung $=\frac{43,3}{34,2}=1,2$. F tabel sebesar 4,38 dengan taraf signifikansi yang dipakai adalah $\alpha=0,05$. Berdasarkan hasil pengolahan data tersebut terungkap bahwa nilai $\mathrm{F}$ hitung lebih kecil dari F tabel, hal ini dapat disimpulkan bahwa varian dari data kemampuan kognitif terhadap kemampuan sikap keagamaan siswa adalah homogen, yang diartikan bahwa data memiliki varian yang sama.

\section{E. Simpulan}

Dari pembahasan dan hasil penelitian yang telah dijelaskan tersebut terungkap bahwa ukuran-ukuran keragaman data statistik (variasi/varian) variabel kemampuan kognitif memiliki kesamaan data kemampuan sikap pada mata pelajaran pendidikan agama Islam. Hal ini dapat mengungkapkan asumsi bahwa variabel kemampuan kognitif dan variabel kemampuan sikap berdasarkan data yang didapat dari responden dengan pengolahan data melalui uji homogenitas dua variabel menggunakan perhitungan manual terbukti bersifat homogen dan layak untuk dilanjutkan ketahap uji berikutnya yaitu analisis uji perbedaan, analisis korelasi sederhana, analisis korelasi ganda dan regresi atau analisis uji normalitas datanya. Dapat disarankan untuk penelitian selanjutnya sebagai contoh adalah pengaruh kemampuan kognitif dan kemampuan sikap terhadap penguasaan materi mata pelajaran agama Islam untuk tingkat sekolah menengah atas atau sederajat. 


\section{F. Daftar Pustaka}

Ahmadi dan Salimi. Dasar-dasar Pendidikan Agama Islam. Jakarta: Bumi Aksara, 1991

Ahmadi. Ilmu Pendidikan. Jakarta, Rineka Cipta, 2003

Amalia, A.R., M. Bakri, dan M. Sulistiono. "Sistem Pembelajaran Pendidikan Agama Islam (Analisis Kritis Teori Konvergensi di SMA Islam Almaarif Singosari)." Vicratina: Jurnal Pendidikan Islam, Vol. 4, No. 3 (2019): 111

Amir. Merancang Kuesioner: Konsep dan Panduan untuk Penelitian Sikap, Kepribadian, dan Perilaku. Jakarta: Prenada Media, 2017

Basri. Filsafat Pendidikan Islam. Bandung, Pustaka Setia, 2009

Dudek. "Homogenity Analysis of Copper Abundance in CU-AG Lubin Deposit using Statistical Procedures." International Multidisciplinary Scientific GeoConference: SGEM, Vol. 19, No. 1.1 (2019): 260

Elihami dan Syahid. "Penerapan Pembelajaran Pendidikan Agama Islam dalam Membentuk Karakter Pribadi yang Islami." Edumaspul: Jurnal Pendidikan, Vol. 2, No. 1 (2018): 80

Gabriel. "A Procedure for Testing the Homogeneity of All Sets of Means in Analysis of Variance.” Biometrics, Vol. 20, No. 3 (1964): 470

Goleman. Kecerdasan Emosional. Jakarta: Gramedia Pustaka Utama, 2000

Hijriati. "Tahapan Perkembangan Kognitif pada Masa Early Childhood." Bunayya: Jurnal Pendidikan Anak, Vol. 1, No. 2 (2017): 35

Jayanti dan Silaen. "Hubungan antara Keharmonisan Keluarga dan Kecerdasan Emosi dengan Kecenderungan Perilaku Delinkuen pada Siswa SMK Adi Luhur 2 Jakarta Timur." IKRA-ITH HUMANIORA: Jurnal Sosial dan Humaniora, Vol. 3, No. 2 (2019): 47

Lillo Flores dan Romo. "Homogeneity Test for Functional Data." Journal of Applied Statistics, Vol. 45, No. 5 (2018): 870

Mardianto. Psikologi Pendidikan. Medan: Cita Pustaka. 2009

Masrom, et.al. Kedudukan Taksonomi Bloom Menurut Perspektif Islam.” Journal of Quran Sunnah Education \& Special Needs, Vol. 2, No. 1 (2018): 20

Michailidis dan de Leeuw. "Multilevel Homogeneity Analysis with Differential Weighting." Computational Statistics \& Data Analysis, Vol. 32, No. 3-4 (2000): 422

Nasution. Filsafat Islam. Jakarta: Gaya Media Pratama, 1999

Poerwadarminta. Kamus Baru Dalam Psikologi Pembelajaran. Jakarta: Bumi Aksara. 2008

Putra. "Konsep Pendidikan Agama Islam Perspektif Imam Al-Ghazali." Jurnal Pendidikan Agama Islam Al-Thariqah, Vol. 1, No. 1 (2017): 42

Ramdhani. "Lingkungan Pendidikan dalam Implementasi Pendidikan Karakter." Jurnal Pendidikan UNIGA, Vol. 8, No. 1 (2014): 28-37 
Candra Wijaya, Muhammad Syafi'i, dan Tongat: Pengaruh Kemampuan Berpikir terhadap Perilaku Siswa (Studi Kasus pada Pelajaran Agama Islam)

Roszi. "Tipologi Perilaku Keagamaan Siswa dan Kemampuan Kognitif pada Pembelajaran Pendidikan Agama Islam di MTs. Batang Kabung Kota Padang." Jurnal El-Rusyd, Vol. 1, No. 1 (2017): 83

Said. Filsafat Pendidikan Islam. Yogyakarta, Mitra Usaha, 2011

Saripudin. "Analisis Tumbuh Kembang Anak Ditinjau dari Aspek Perkembangan Motorik Kasar Anak Usia Dini." Equalita: Jurnal Pusat Studi Gender dan Anak, Vol. 1, No. 1 (2019): 116

Setiawan. "Kajian Kurikulum Pendidikan Agama Islam dalam Tinjauan Historis, Sosiologi, Politis, Ekonomis dan Manajemen Negara." Darul Ulum: Jurnal Ilmiah Keagamaan, Pendidikan dan Kemasyarakatan, Vol. 9, No. 2 (2018): 253-275

Sitorus. Perkembangan Peserta Didik. Depok: Kencana, 2017

Syah. Psikologi Belajar. Jakarta: Raja Grafindo Persada, 2009

Tenenhaus dan Young. "An Analysis and Synthesis of Multiple Correspondence Analysis, Optimal Scaling, Dual Scaling, Homogeneity Analysis and Other Methods for Quantifying Categorical Multivariate Data." Psychometrika, Vol. 50, No. 1 (1985: 100

Wati. "Memahami Perkembangan Jiwa Keagamaan pada Anak dan Remaja." FOKUS Jurnal Kajian Keislaman dan Kemasyarakatan, Vol. 1, No. 1 (2016): 21

Wijaya. "Reformasi Pendidikan Islam.” Prosiding Seminar Nasional, Vol. 105 (2016).

Yahya, S.A. and Nasrun, S. Tahap Penghayatan Agama Dalam Kalangan Remaja Hamil Tanpa Nikah.” Jurnal Sains Sosial@ Malaysian Journal of Social Sciences, Vol. 1, No. 1 (2016): 19

Yusuf, Metode Penelitian Kuantitatif, Kualitatif dan Penelitian Gabungan. Jakarta: Kencana Prenadamedia Group. 2014 